\title{
Landfill Pollution Plume Survey in the Moroccan Tadla Using Spontaneous Potential
}

\author{
Yousra El Mouine 1,2,3,*, Amal El Hamdi 1,2,3, Moad Morarech ${ }^{2}\left(\mathbb{0}\right.$, Ilias Kacimi ${ }^{4}$, Meryem Touzani ${ }^{4}$, \\ Ismail Mohsine ${ }^{4}$, Abdessamad Tiouiouine ${ }^{4}$, Jamila Ouardi ${ }^{4}{ }^{,}$Abdelmajid Zouahri ${ }^{3}$, Hasna Yachou ${ }^{3}$ \\ and Houria Dakak ${ }^{3}$ \\ 1 Laboratory Mediterranean Environment and Agro-Hydrosystem Modelling (UMR 1114 EMMAH), \\ Hydrogeology Department, Avignon University, 84000 Avignon, France; amalgoaea@gmail.com \\ 2 Laboratory in Applied and Marine Geosciences, Geotechnics and Georisk (LR3G) Faculty of Science Tetouan, \\ Abdelmalek Essaâdi University, 93002 Tetouan, Morocco; morarech2000@gmail.com \\ 3 National Research Institute of Agricultural Research (INRA), CRRAR, URECRN, 1000 Rabat, Morocco; \\ zouahri@yahoo.fr (A.Z.); hasnayachou@gmail.com (H.Y.); dakak_h@yahoo.fr (H.D.) \\ 4 Laboratory of Geoscience, Water and Environment, (LG2E-CERNE2D), Department of Earth Sciences, \\ Faculty of Sciences, Mohammed V University of Rabat, 1014 RP Rabat, Morocco; iliaskacimi@yahoo.fr (I.K.); \\ touzani.doc@gmail.com (M.T.); mohsine.ismail@gmail.com (I.M.); touiouineas@gmail.com (A.T.); \\ jouardi@yahoo.fr (J.O.) \\ * Correspondence: yousra.elmouine@gmail.com
}

\section{check for} updates

Citation: El Mouine, Y.; El Hamdi, A.; Morarech, M.; Kacimi, I.; Touzani, M.; Mohsine, I.; Tiouiouine, A.; Ouardi, J.; Zouahri, A.; Yachou, H.; et al. Landfill Pollution Plume Survey in the Moroccan Tadla Using Spontaneous Potential. Water 2021, 13, 910. https://doi.org/10.3390/ w13070910

Academic Editor:

Alexander Yakirevich

Received: 14 February 2021

Accepted: 12 March 2021

Published: 26 March 2021

Publisher's Note: MDPI stays neutral with regard to jurisdictional claims in published maps and institutional affiliations.

Copyright: (c) 2021 by the authors. Licensee MDPI, Basel, Switzerland. This article is an open access article distributed under the terms and conditions of the Creative Commons Attribution (CC BY) license (https:/ / creativecommons.org/licenses/by/ $4.0 /)$.

\begin{abstract}
In many parts of the world, the impact of open landfills on soils, biosphere, and groundwater has become a major concern. These landfills frequently generate pollution plumes, the contours of which can be delineated by non-intrusive geophysical measurements, but in arid environments, the high soils resistivity is usually an obstacle, which results in the low number of studies that have been carried out there. In addition, such prospecting using geophysical techniques do not provide information on the intensity of the processes occurring in the water table. This study was carried out on an uncontrolled landfill in the arid Tadla plain, Morocco's main agricultural region. A survey based on geo-referenced spontaneous potential measurements was combined with measurements of anoxic conditions (Eh-pH and $\mathrm{O}_{2}$ equilibrating partial pressure) in the groundwater and leachates, in order to highlight a pollution plume and its geometry. The range of spontaneous potential measurement is wide, reaching $155 \mathrm{mV}$. Ponds of leachate with high electrical conductivity (20 to $40 \mathrm{mS} \mathrm{cm}^{-1}$ ) form within the landfill, and present very reducing conditions down to sulphate reduction and methanisation. The plume is slowly but continuously supplied with these highly reducing and organic carbon-rich leachates from the landfill. Its direction is towards N-NW, stable throughout the season, and consistent with local knowledge of groundwater flow. The fast flow of the water table suggests pollution over long distances that should be monitored in the future. The results obtained are spatially contrasting and stable, and show that such techniques can be used on a resistive medium of arid environments.
\end{abstract}

Keywords: self-potential; redox potential; leachate plume; landfill; Tadla; Morocco

\section{Introduction}

Discharging into open, uncontrolled or semi-controlled landfills is one of the cheapest procedures for the disposal of solid waste. It is therefore a widespread municipal practice in many parts of the world [1-5]. They constitute potential sources of various kinds of pollutant as fermentation in these landfills generates leachate that contain a broad spectrum of xenobiotic organic or inorganic pollutants that can contaminate surrounding groundwater, often a scarce water resource [6], and sometime over long distances (usually several hundreds of metres) [7]. Water flows within the waste and soil facilitate the redistribution of chemicals, microorganisms and nutrients, and the flow of pollutants 
into groundwater forms a contaminant plume in the aquifer system [8]. Water is thus the main vector of contamination, but it is also necessary for hydrolysis, the first step in the anaerobic degradation process. Given the invisibility and complexity of the groundwater environment, delineating the extent of a pollution plume is generally difficult and costly, as is access to the characteristics of polluted groundwater [9]. Geophysical tools using non-intrusive techniques are the most suitable tools for delineating the contour of a plume. Among all the relevant geophysical techniques, spontaneous potential (or self-potential, SP) measurements have been used for some thirty years in contamination studies of household waste landfills. More specifically, contamination studies have recently multiplied due to the high sensitivity of SP to redox conditions in shallow aquifers [10-12]. Indeed, spontaneous potential detectable at the soil surface, is sensitive to spatial variations in charge flow within the matrix, oxidation-reduction gradients, temperature variations, microorganism signals or other activities accompanied by contaminant migration [13-19]. The delimitation of a plume also makes it possible to locate groundwater access points more precisely for the characterisation or monitoring of the microbiological and chemical status of the groundwater $[20,21]$. However, in the literature, the application of these geophysical methods mainly concerns industrialised countries, and they are rarely applied to African countries in general, and Morocco in particular. This study, carried out in the agricultural region of Moroccan Tadla, aims to delimit the extension of the plume of pollution of the water table generated by an open and uncontrolled dumpsite, as well as the direction of propagation and its stability following the seasonal irrigation of the surrounding plots. Measurements of spontaneous potential are associated with a physico-chemical characterisation of irrigation water, drainage water, landfill leachate, and groundwater in order to identify the intensity the processes involved and accompanying the genesis of the plume.

\section{Materials and Methods}

\subsection{Study Area}

The study was carried out on the Souk-Sebt landfill, an uncontrolled landfill of about 8 ha in the Tadla plain, the main agricultural production region of Morocco (Figure 1). On a regional scale, the Tadla plain, characterised by an arid climate, is supplied with water by the Atlas Mountains in the south. In addition to this natural supply, there is a powerful irrigation network coming from the Bin El Ouidane dam, located about $100 \mathrm{~km}$ upstream from the area. This network, set up at the end of the 90s, is already old and has numerous leaks contributing locally to the recharge of the water table. The climate is continental semi-arid to arid, with a dry season from April to October and a wet season from November to March. The inter-annual average temperature is about of $20^{\circ} \mathrm{C}$ and the annual average rainfall about $430 \mathrm{~mm}$ [22]. The plain is drained by the river Oum Er Rbia that crosses it in its centre from east to west. The study site is on the left bank, and the water table at a depth of 5 to $6 \mathrm{~m}$ under an indurated limestone crust flows regionally towards the north-northwest [23]. Regionally, it fluctuates due to recharge during irrigation periods. On the surface, the soils have a fine texture and moderate permeability. Land use is intense and the population, in scattered settlements [24], also uses water from wells for washing, drinking and cooking. There are numerous unauthorised landfills [25], and the delimitation of pollution plumes from these landfills is therefore of major health interest. The Souk-Sebt landfill is surrounded by agricultural plots that are generally irrigated from the end of April to the end of June. This landfill mainly receives household and agricultural waste, but more recently, organic residues from a beet sugar production plant are regularly dumped there. The soil of the landfill, compacted by the weight of the trucks unloading the waste, is not very permeable and the leachate only infiltrates very slowly. During the winter period, the rains, although not very abundant, are sufficient to generate pools of leachate, the local depth of which can reach 1 metre and the extension of which can be several tens of square metres each. 


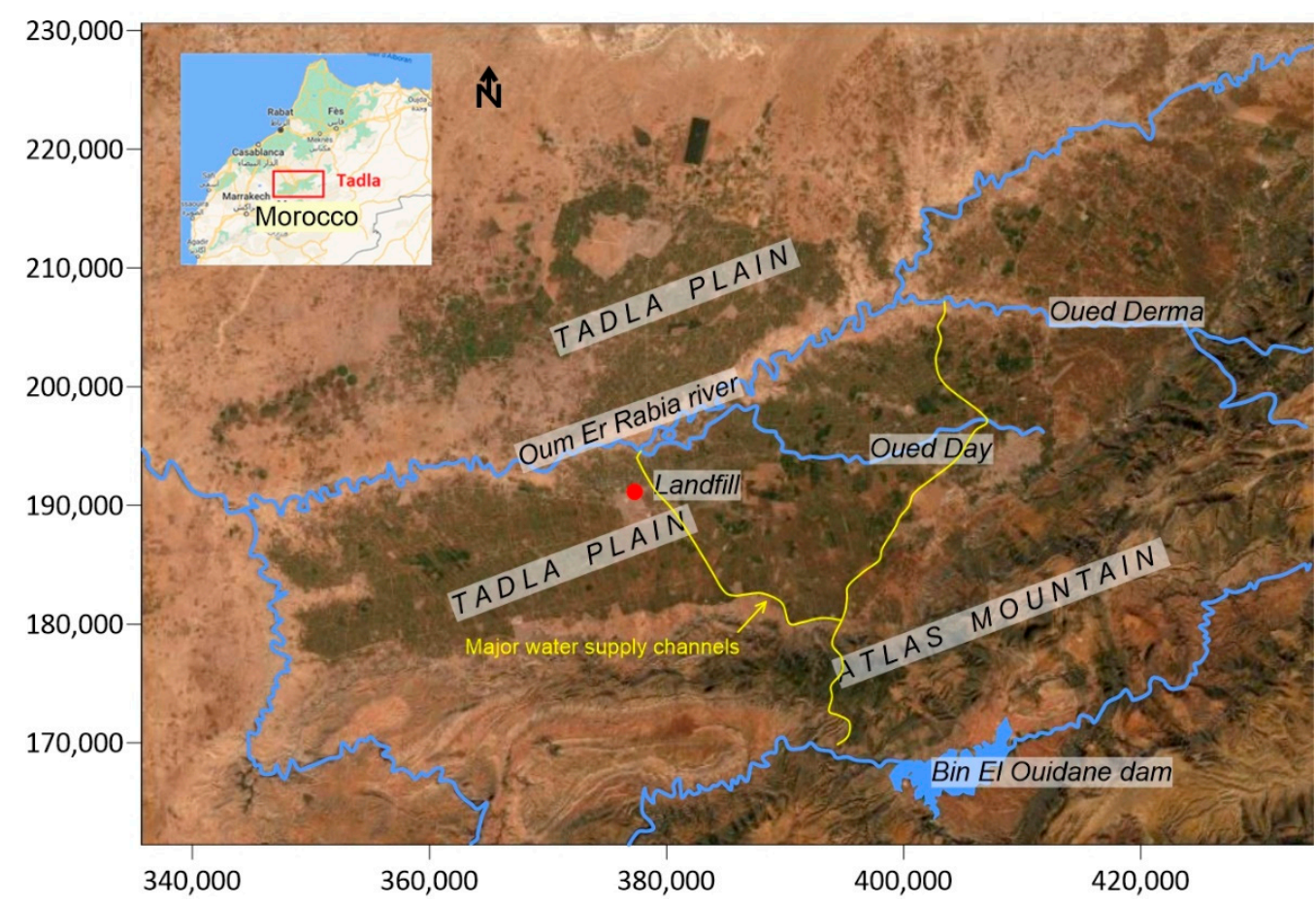

Figure 1. Geographical framework and location of the Souk-Sebt landfill in the Tadla plain. UTM coordinates in metre using Lambert conical conformal projection (Morocco zone 1).

\subsection{Spontaneous Potential Measurement}

The material used consists of two impolarisable electrodes PMS9000, $\mathrm{Pb} / \mathrm{PcCl} 2$, $\mathrm{NaCl}$ [26]. These electrodes are sealed with porous wood and an electrolytic solution of $\mathrm{NaCl}$ ensures electrical continuity between the inside of the electrode and the soil. The voltage measurement was carried out using a Widewing Multimeter UNI-T UT71A voltmeter (Petiau type, SDEC, Rousset, France) with an input impedance of $10 \mathrm{M} \Omega$. This high impedance value ensures good measurement quality. One of the electrodes is fixed, used as a reference potential, and the second is mobile. The latter is moved successively over the different points of the studied terrain. The cable used is a flexible cable made up of two copper strands with a cross-section of $0.75 \mathrm{~mm}^{2}$. To ensure good electrical contact between the ground and the electrode, the electrode is inserted in a superficial auger hole $(10 \mathrm{~cm})$ filled with a mud made with the earth taken with an auger mixed with slightly mineralised water. The measurement is noted when the measured potential is stabilised, i.e., when the voltage fluctuations do not exceed $2 \mathrm{mV}$. The GPS coordinates are recorded for each measuring point. The measurements were carried out in 3 campaigns, to ensure that the results do not reflect an ephemeral situation. The first campaign was carried out in April 2020 before the irrigation period, and the two others in June and July 2020 corresponding to the period of groundwater recharge through irrigation. During each campaign, measurements of spontaneous potential were carried out all around the landfill to compare the upstream and downstream situations according to regional groundwater flows.

\subsection{Redox Potential and Physicochemical Measurements}

Measurements of temperature, electrical conductivity, $\mathrm{pH}$ and redox potential were carried out in the field, in situ in the leachate, and on samples taken from the water table from wells and boreholes located around the landfill, as well as from plot drains and irrigation water. The equipment used is a Hanna Instrument HI98150 pH-meter (Hanna Instrument, Lingolsheim, France). The redox electrode is a platinum electrode with a $\mathrm{KCl} / \mathrm{AgCl} 2$ half electrode. The potential of the half electrode, which is temperaturedependent, has been added to the voltmeter reading to obtain the redox potential Eh. The redox measurements were carried out on site, taking care not to cause oxygenation of 
the medium during measurements and sampling. In order to reduce the time needed to stabilise the measurements when changing redox environments, the measurement campaigns were grouped together, i.e., all the measurements in the leachate were grouped together on the same day, then the measurements in the groundwater or irrigation water were carried out the next day, for each campaign (April, June and July 2020). The 9 wells closest to the landfill, and located both upstream (South and East sectors) and downstream (West and North sectors) were characterised in situ and sampled, and 11 measurement points were defined for monitoring the characteristics of the irrigation and drainage water in the plots. Finally, 27 measurement points on seasonal leachate ponds were characterised inside the landfill. All the characterisation points are grouped together in Figure 2.
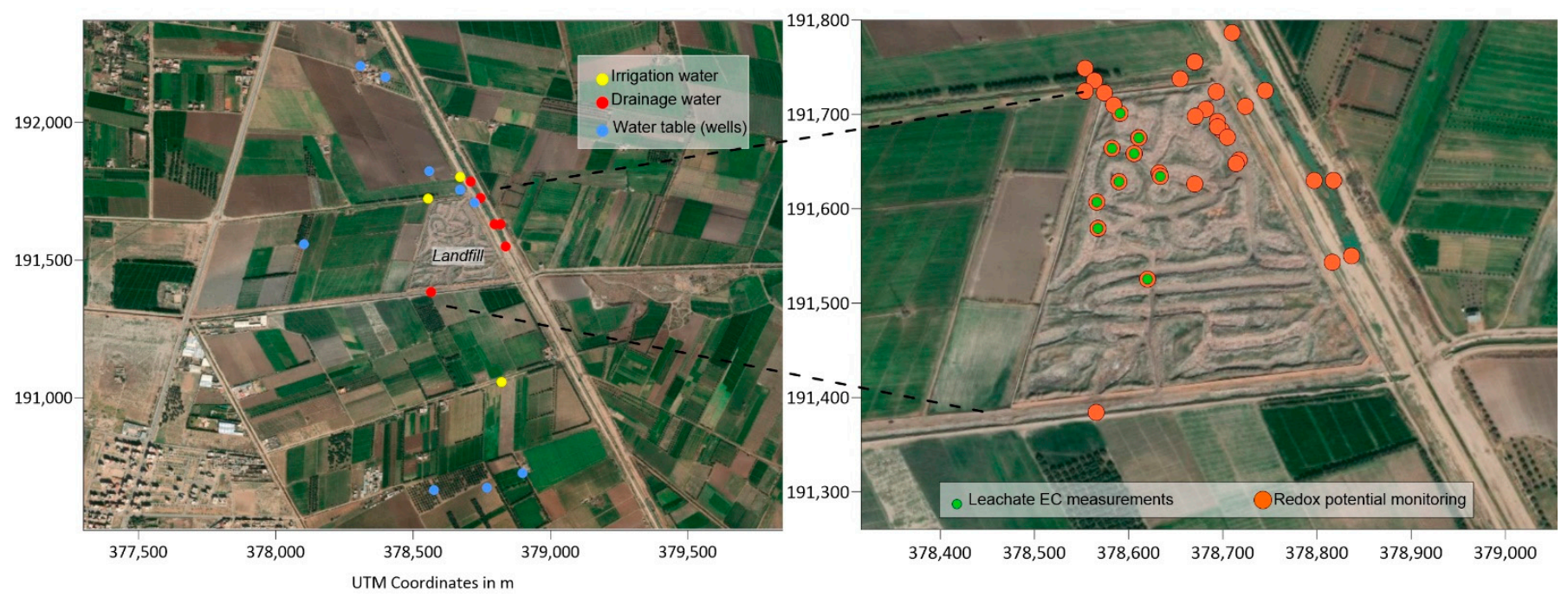

Figure 2. Location map of water characterisations measurement points (irrigation, drainage, groundwater and leachate water). Note that the waste is grouped in windrows within the landfill. UTM coordinates in metre using Lambert conical conformal projection (Morocco zone 1).

\subsection{Field Data Treatments}

The redox potential values obtained are presented on the Pourbaix diagrams for the various chemical elements ( $\mathrm{N}, \mathrm{Fe}, \mathrm{S}$ and $\mathrm{C}$ ). The equilibrium oxygen pressure $\mathrm{pO}_{2}$ has been calculated from thermodynamic data from the dissociation equilibrium of water:

$$
2 \mathrm{H}_{2} \mathrm{O} \leftrightarrow 4 \mathrm{H}++4 \mathrm{e}-+\mathrm{O}_{2}(\mathrm{~g}),
$$

This reaction has slow kinetics leading to thermodynamic non-equilibrium [27]. The calculation of the equilibrating $\mathrm{O}_{2}$ partial pressure offers the advantage of combining $\mathrm{pH}$ and Eh measurements in order to estimate a global parameter of anoxia, i.e., $\log \left(\mathrm{pO}_{2}\right)$.

\subsection{Mapping Tools}

The mapping of the results was carried out with the Surfer software (Golden Software, LLC, 809 14th Street, Golden, CO, USA). As the number of measurement points during each campaign was insufficient for a geostatistical study, extrapolation between the measurement points was carried out by default on the basis of an unbounded linear variogram.

\section{Results}

\subsection{Self Potential Survey}

A total of 165 spontaneous potential measurement points were carried out over the 3 campaigns inside and outside the landfill. The range of values is wide, from $+90 \mathrm{mV}$ observed to the south east, outside the landfill to $-65 \mathrm{mV}$ observed inside the landfill. Mean values and standard deviation are presented in Table 1. The SP measurements carried 
out outside the landfill show a relative stability over time, from one campaign to another. Some rare differences appear on the western edge of the landfill with values alternately shifting from negative to positive and then negative again depending on the 3 campaigns. Due to this stability over time, the results of the three campaigns have been grouped together and are presented in Figure 3, where the negative values, likely associated to low redox conditions, indicate the position and direction of the pollution plume towards the north-northwest of the landfill (Figure 3). The measurement points that differed between the campaigns were found to be located at the very edge of the plume. On the other hand, inside the landfill the observed values were always negative, but there was a greater variation between measurement campaigns. These variations accompany the restructuring of the waste swaths as trucks pass by, the dumping of newer waste and the relocation of low points and leachate ponds.

Table 1. Mean SP Values and standard deviation inside and outside the landfill.

\begin{tabular}{cccc}
\hline Self Potential $\mathbf{~} \mathbf{V}$ & & Mean & Standard Deviation \\
\hline Inside the Landfill & & -6.37 & 5.62 \\
Outside the landfill & Inside plume & -7.3 & 4.41 \\
& Outside plume & +16.08 & 13.27 \\
\hline
\end{tabular}
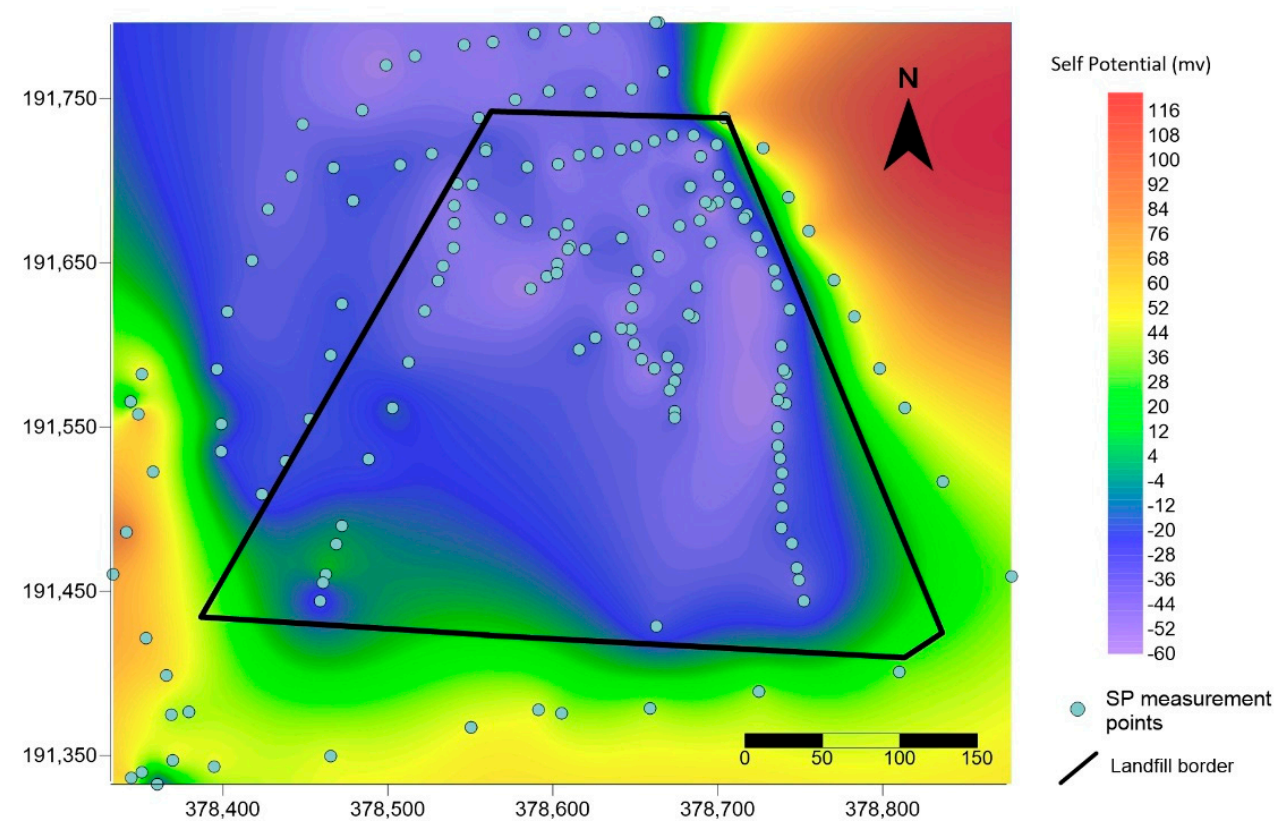

Figure 3. Survey regrouping of self-potential results obtained during the 3 measurement campaigns in and around the landfill. UTM coordinates in metre using Lambert conical conformal projection (Morocco zone 1).

\subsection{Redox Potential, $\mathrm{pH}$ and Electrical Conductivity}

Within the landfill, several types of leachate of different colours and fluidity could be distinguished. The dominant colour was black, characterising leachates rich in dissolved and particulate organic carbon. A distinction was made according to the depth of the measurement, i.e., on the surface or at the bottom of the leachate pond. Some leachates showed a green to red colour, reflecting photosynthetic activity, while others were white. The electrical conductivity values of the leachate were high, between 20 and $40 \mathrm{mS} \mathrm{cm}^{-1}$ (Table 2). 
Table 2. Mean electrical conductivity and standard deviation for leachates, irrigation water, drain water and watertable around the landfill.

\begin{tabular}{ccc}
\hline EC $\left(\mathbf{m S ~ c m}^{-\mathbf{1}}\right)$ & Mean & Standard Deviation \\
\hline leachate & 33.35 & 5.44 \\
irrigation water & 0.52 & 0.01 \\
watertable & 0.83 & 0.19 \\
Drain water & 0.51 & 0.01 \\
\hline
\end{tabular}

The redox potential ranged from -0.16 to +0.1 Volts, with a $\mathrm{pH}$ range of 6 to 8.35 . The combination of these values is shown in the Pourbaix diagrams of nitrogen, iron, sulphur and carbon (Figure $4 \mathrm{a}-\mathrm{d}$ ). The equilibrating partial pressure according to the type of leachate is presented in Figure 5. The range was from 10-63 to 10-50 atm. The leachate typology observed and mentioned above seemed to correspond to different degrees of reduction, with red or green leachates showing the least reducing values. Similarly, there was a difference between the redox characteristics of surface (slightly less reducing) and depth for black leachate. In addition, during each field campaign, we have always observed a certain amount of waste burning in the landfill.

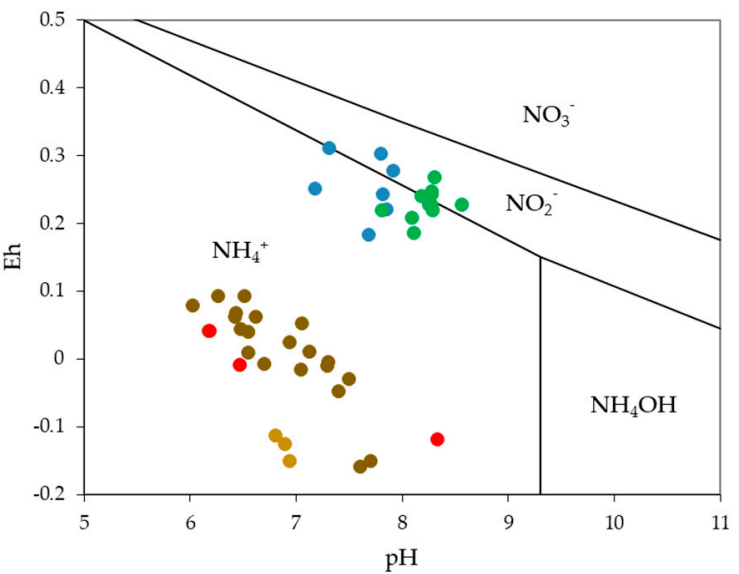

(a)

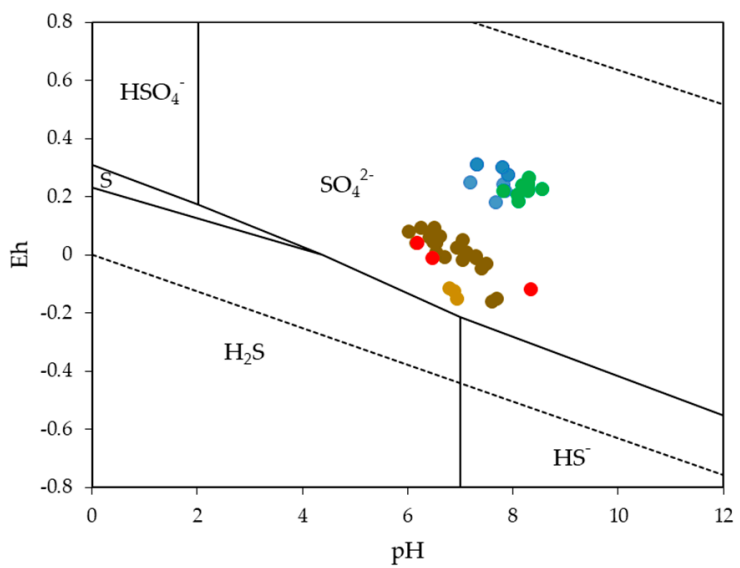

(c)

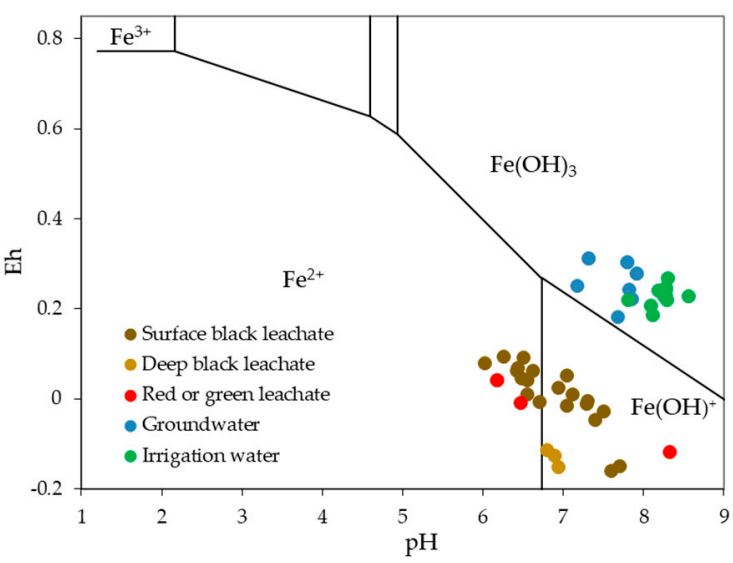

(b)

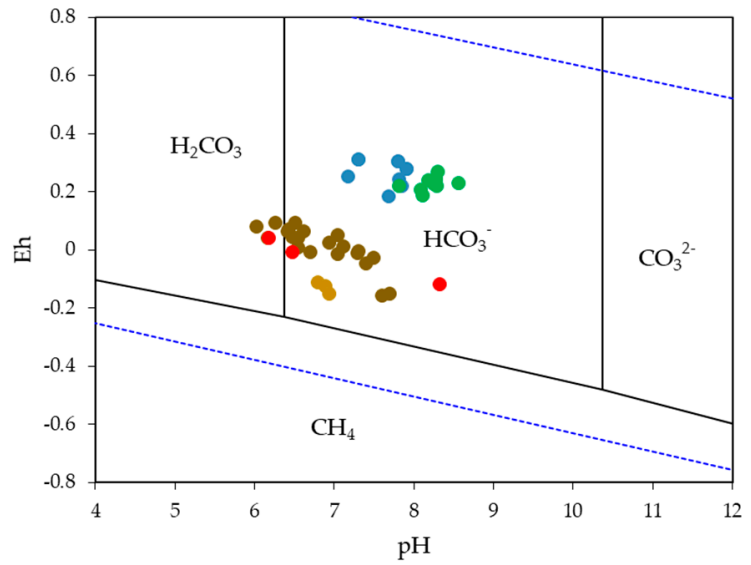

(d)

Figure 4. Pourbaix diagram showing the species stability domains for irrigation water, ground water and leachates for (a) N, (b) Fe, (c) S, and (d) C. 


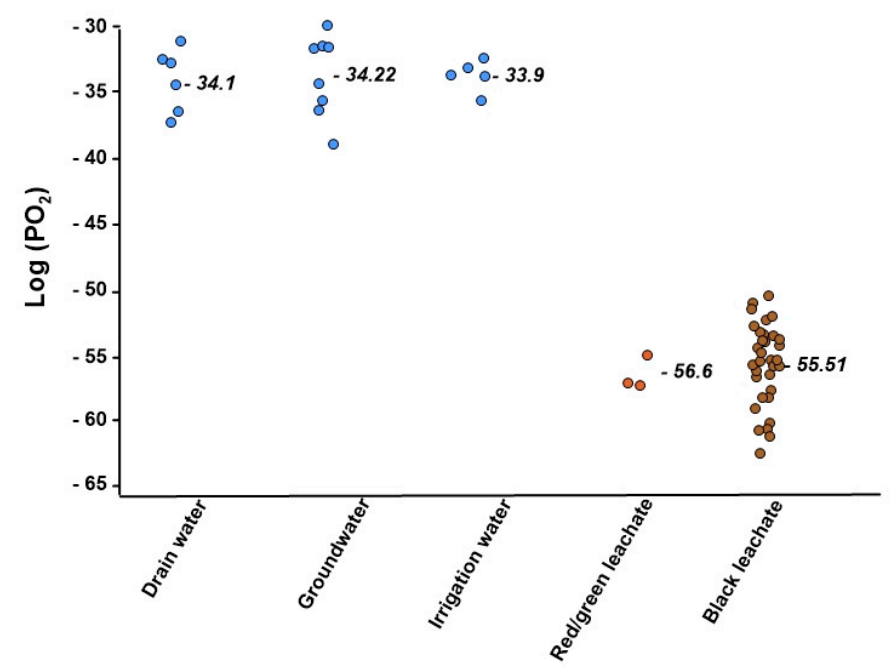

Figure 5. Bulk and mean value of calculated oxygen-equilibrating partial pressure for irrigation-, drainage-, ground-water and leachates.

Outside the landfill, the electrical conductivity of irrigation and drainage water was of the same order of magnitude, with averages of 0.52 and $0.51 \mathrm{mS} \mathrm{cm}^{-1}$, respectively. Ground water, on the other hand, was slightly more mineralised, with an average value of $0.83 \mathrm{mS} \mathrm{cm}^{-1}$. Among the few data collected, no trend of higher minerality was observed downstream of the landfill (Figure 6), but the sampled wells are only the existing wells closest to the landfill and appear to be outside the pollution plume. The lowest values found (about $0.6 \mathrm{mS} \mathrm{cm}^{-1}$ ) were immediately north of the landfill, but close to the irrigation canal. On the whole, groundwater was rather oxidising with an equilibrating $\mathrm{O}_{2}$ partial pressure in the order of 10-33 atm (Figure 5). The redox potential ranged from 0.18 to $0.27 \mathrm{~V}$, and the $\mathrm{pH}$ from 7.8 to 8.6 (Figure 4).

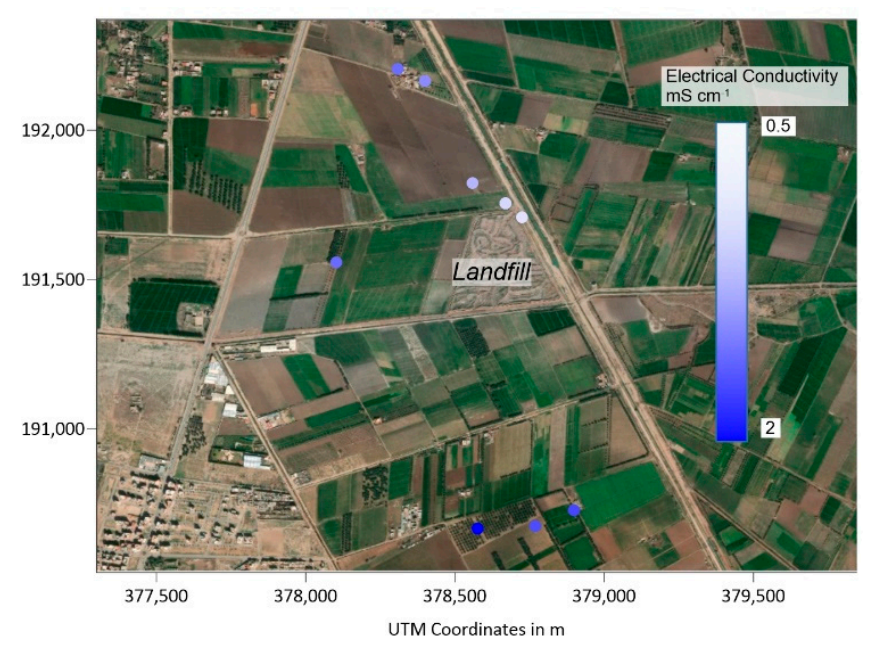

(a)

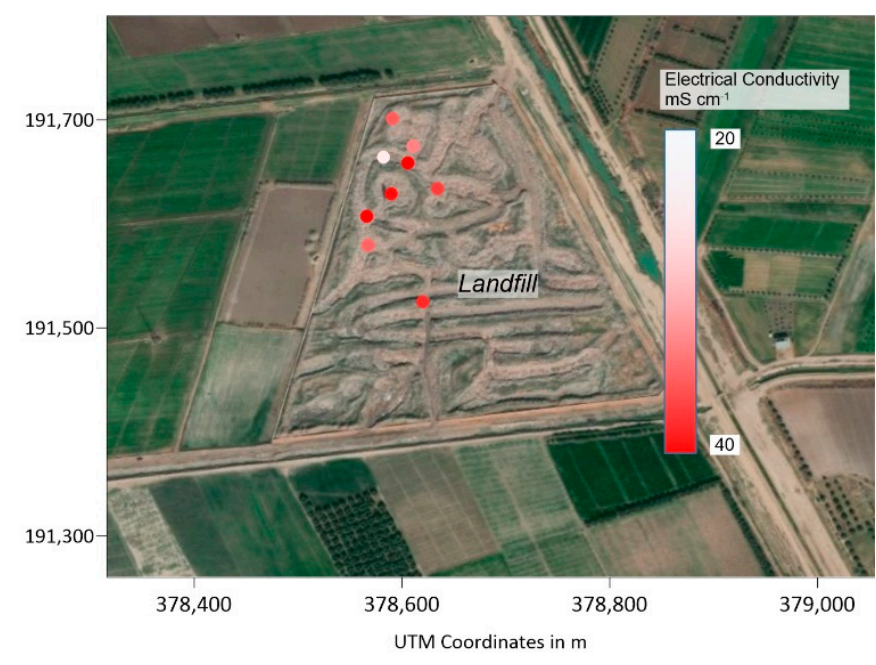

(b)

Figure 6. Distribution of electrical conductivity (a) in the watertable, and (b) in the leachates.

\section{Discussion}

\subsection{Plume Detection and Stability throughout the Season}

The measurement of spontaneous potential appears to be suitable for the detection of the pollution plume in this arid region. The difference between the outside and inside of the plume (mean values of $+16.1 \mathrm{mV}$ and $-7.4 \mathrm{mV}$ respectively, Table 1) illustrates the reliability and representativeness of the spontaneous potential measurements. This 
difference is high compared to the variability within each area (standard deviations of 4.4 and $13.3 \mathrm{mV}$ ) and the values measured in the landfill are consistent with those collected in the plume outside the landfill. Low and/or negative spontaneous potential values are organised similarly during each field campaign. Very slight differences were detected on the western edge of the landfill that can be attributed to a slight change in groundwater flow due to the strong increase in irrigation in the summer period, with a resulting increase in groundwater recharge. This change remains minimal and reflects a slight shift in the plume edge. Overall, irrigation and local groundwater recharge do not appear to significantly alter the orientation of the pollution plume. The plume appears clearly on the mapping at the hydrogeological downstream of the landfill, and confirms a contamination of the groundwater table by leachate. It seems relatively narrow and do not exceed the width of the landfill. Two mechanisms are likely to be at the origin of the SP field. The electrical conductivity of the watertable being slightly more charged, the displacement of these charged ions within the porous matrix generates an electrokinetic potential. On the other hand, the gradients of redox conditions within the plume are probably at the origin of an electrochemical potential. The response obtained and shown in Figure 3 is probably a combination of these two effects, electrokinetic and electrochemical. An hydrochemical study of well waters further downstream of the landfill is planned to specify the various mechanisms involved in the self potential field.

\subsection{A Real but Fairly Moderate Contamination}

Groundwater is slightly more mineralised than irrigation water, partly due to evaporation in irrigated plots. On the other hand, leachates have a dissolved ionic charge between 20 and 80 times higher than that of groundwater or irrigation water. However, there is no clear increase in the minerality of the groundwater to the north-west of the landfill, possibly due to (1) the lack of access to the groundwater inside the pollution plume during field campaigns, (2) probable dilution of these wells by irrigation water from the canal in the vicinity, but also (3) the fact that the leachate flow reaching the groundwater is low compared to the groundwater flow. This result can be explained by the low permeability of the fine-textured soils that are compacted by the passage of loaded trucks that come to deposit the waste in the landfill. The low permeability under the landfill also explains the presence of leachate ponds that remain throughout the season despite the low rainfall. The redox conditions observed in the field vary considerably between irrigation water, drainage water, groundwater and the different types of leachate. In general, the groundwater presents oxidizing redox conditions close to those of the irrigation water, but the measurements made on the wells near and north of the landfill show conditions that exceed an anoxia favourable for denitrification (Figure 4a) and approaching the FeIII/FeII equilibrium limit (Figure $4 b$ ). Thus, despite a fairly low electrical conductivity, it reflects a fairly high level of contamination. The punctual EC measurement remains moderate, which reinforces the interest of a survey using spontaneous potential method. It allows a higher density of information, and is sensitive both the spatial modification of the ion flux (EC) and the gradient of redox conditions. Two spontaneous potential measurement lines were carried out downstream of the landfill and during two different periods. The stability of the results obtained suggests permanent contamination and propagation over long distances due to the high flow of the water table. The impact on groundwater quality is all the more alarming as the rural populations of this region are directly pumping from the aquifer for their water supply due to the isolation of the dwellings. Uncontrolled landfills are numerous, and water quality should therefore be monitored within dwellings located in the direction of the spread of pollution plumes [22]. In addition, recent surveys of farmers (unpublished) suggest agricultural land degradation along the plume axis, resulting in many problems of olive tree growth or degradation. Geophysical measurements are planned in order to better understand the context that may explain such degradation. For many contaminants, the attenuation processes provide significant natural remediation, limiting the effects of the leachate on the groundwater to an area usually not exceeding $1000 \mathrm{~m}$ from the landfill [7]. 
A future field campaign will also have to focus on wells several hundred metres away from the discharge, in the axis of the detected pollution plume.

\subsection{Ongoing Processes in the Leachate}

Within the landfill, a strong spatial and temporal heterogeneity of SP values was observed from one campaign to the next. This heterogeneity contrasts with the regular and progressive evolutions observed outside the landfill. Such spatial variability reflects the presence of hot spots, punctual zones of intense fermentation of recent organic waste. Such hot spots are common and have been observed in other landfills [17,28-30]. The constant re-shuffling of waste by trucks and the constant influx of new waste means that these hot spots are quite transient and differ from one campaign to another. The redox conditions found in the leachates are very reductive, approaching conditions favourable to the sulphate-reduction (Figure $4 \mathrm{c}$ ) and methanisation (Figure $4 \mathrm{~d}$ ) processes, with very low equilibrating oxygen partial pressures. The permanent combustion of the waste must be attributed to the production of methane. These conditions are not spatially homogenous, as the distinction between the types of leachate according to their colour reflects different degrees of reduction. Even for the black leachates, the most reducing, it can be seen that on the surface of the ponds an adsorption of oxygen from the air allows a slight oxidation, a phenomenon which is nevertheless insufficient to oxidise the leachate. The biological activity, abundantly nourished by the high organic carbon content, maintains very reducing conditions.

\section{Conclusions}

Our study of a landfill site in the Moroccan Tadla Plain confirms the presence of a plume of water table contamination by leachates, a plume that extends in the regional direction of groundwater flow. Due to the easily fermentable organic carbon-rich composition, the fermentation processes within the landfill are extreme and leachates production is high. Given the population density and land use, the study raises a worrying health problem, directly due to the use of groundwater loaded with organic pollutants, metals, bacteria and other toxic elements from the landfill, or indirectly due to the recycling of these pollutants through irrigated agricultural activity. On the surface, the low permeability of the soil, due to its fine texture and the compaction by trucks, leads to the formation of leachate ponds. In this context, leachate infiltration is slow but continuous. The low flow of leachate that reaches the water table does not cause a significant change in electrical conductivity, but the input of highly biodegradable dissolved organic carbon leads to a plume marked by reducing processes that contrast with the oxidising conditions upstream of the landfill. This plume and its propagation towards the north-north-west are clearly shown by spontaneous potential survey, and measurements taken over several periods show the permanence and directional stability of the plume, which are little impacted by the irrigation of the surrounding plots. The high groundwater flow probably favours long-distance contamination, a point that will have to be confirmed in the future.

Author Contributions: Project administration, Y.E.M.; conceptualization, formal analysis, funding acquisition, resources, Y.E.M., M.M. and A.E.H.; methodology, M.M.; software, Y.E.M., A.E.H., and H.D.; investigation, I.K. and A.Z.; data curation, Y.E.M., A.E.H., and M.M.; writing-original draft preparation and editing review, Y.E.M., A.E.H., M.M., H.Y., J.O., A.T., I.M., M.T., and H.D.; visualization and validation, A.Z., H.D., and I.K.; supervision, M.M., H.D., and H.Y. All authors have read and agreed to the published version of the manuscript.

Funding: This research received no external funding.

Institutional Review Board Statement: Not applicable.

Informed Consent Statement: Not applicable.

Data Availability Statement: The data presented in this study are available on request from the corresponding author. 
Acknowledgments: The authors thanks to Avignon and Abdelmalek Essaadi universites, and the Dean of National Institute of Agricultural Research. The authors are also greatful to the staff of the Hydrogeology Laboratory of Avignon for their help and support. Critical and constructive review of the manuscript by the reviewers was greatly treasured.

Conflicts of Interest: The authors declare no conflict of interest.

\section{References}

1. Jhamnani, B.; Singh, S.K. Groundwater Contamination due to Bhalaswa Landfill Site in New Delhi. Int. J. Civil Environ. Eng. 2009, $1,121-125$.

2. Longe, E.O.; Balogun, M.R. Groundwater Quality Assessment near a Municipal Landfill, Lagos, Nigeria. Res. J. Appl. Sci. Eng. Technol. 2010, 2, 39-44.

3. Fan, H.; Shu, H.-Y.; Yang, H.-S.; Chen, W.-C. Characteristics of landfill leachates in central Taiwan. Sci. Total Environ. 2006, 361, 25-37. [CrossRef] [PubMed]

4. Kjeldsen, P.; Barlaz, M.A.; Rooker, A.P.; Baun, A.; Ledin, A.; Christensen, T.H. Present and Long-Term Composition of MSW Landfill Leachate: A Review. Crit. Rev. Environ. Sci. Technol. 2002, 32, 297-336. [CrossRef]

5. Mena-Rivera, L.; Salgado-Silva, V.; Benavides-Benavides, C.; Coto-Campos, J.M.; Swinscoe, T.H.A. Spatial and Seasonal Surface Water Quality Assessment in a Tropical Urban Catchment: Burío River, Costa Rica. Water 2017, 9, 558. [CrossRef]

6. Han, Z.; Ma, H.; Shi, G.; He, L.; Wei, L.; Shi, Q. A review of groundwater contamination near municipal solid waste landfill sites in China. Sci. Total Environ. 2016, 569-570, 1255-1264. [CrossRef] [PubMed]

7. Christensen, T.H.; Kjeldsen, P.; Bjerg, P.L.; Jensen, D.L.; Christensen, J.B.; Baun, A.; Albrechtsen, H.-J.; Heron, G. Biogeochemistry of landfill leachate plumes. Appl. Geochem. 2001, 16, 659-718. [CrossRef]

8. Dvorski, S.E.-M.; Gonsior, M.; Hertkorn, N.; Uhl, J.; Müller, H.; Griebler, C.; Schmitt-Kopplin, P. Geochemistry of Dissolved Organic Matter in a Spatially Highly Resolved Groundwater Petroleum Hydrocarbon Plume Cross-Section. Environ. Sci. Technol. 2016, 50, 5536-5546. [CrossRef]

9. $\mathrm{Gu}, \mathrm{X} . ;$ Xiao, Y.; Yin, S.; Shao, J.; Pan, X.; Niu, Y.; Huang, J. Groundwater level response to hydrogeological factors in a semi-arid basin of Beijing, China. J. Water Supply Res. Technol. 2017, 66, 266-278. [CrossRef]

10. Arisalwadi, M. Rahmania Mapping leachate distribution based on the self-potential method in Manggar Landfill, Balikpapan Indonesia. J. Phys. Conf. Ser. 2021, 1763, 12013. [CrossRef]

11. Stanly, R.; Yasala, S.; Oliver, D.H.; Nair, N.C.; Emperumal, K.; Subash, A. Hydrochemical appraisal of groundwater quality for drinking and irrigation: A case study in parts of southwest coast of Tamil Nadu, India. Appl. Water Sci. 2021, 11, 53. [CrossRef]

12. Rani, P.; Piegari, E.; Di Maio, R.; Vitagliano, E.; Soupios, P.; Milano, L. Monitoring time evolution of self-potential anomaly sources by a new global optimization approach. Application to organic contaminant transport. J. Hydrol. 2019, 575, 955-964. [CrossRef]

13. Arora, T.; Linde, N.; Revil, A.; Castermant, J. Non-intrusive characterization of the redox potential of landfill leachate plumes from self-potential data. J. Contam. Hydrol. 2007, 92, 274-292. [CrossRef]

14. Gallas, J.D.F.; Taioli, F.; Malagutti Filho, W. Induced polarization, resistivity, and self-potential: A case history of contamination evaluation due to landfill leakage. Environ. Earth Sci. 2011, 63, 251-261. [CrossRef]

15. Martínez-Pagán, P.; Jardani, A.; Revil, A.; Haas, A. Self-potential monitoring of a salt plume. Geophysics 2010, 75, WA17-WA25. [CrossRef]

16. Naudet, V.; Revil, A.; Bottero, J.-Y.; Bégassat, P. Relationship between self-potential (SP) signals and redox conditions in contaminated groundwater. Geophys. Res. Lett. 2003, 30. [CrossRef]

17. Naudet, V.; Revil, A.; Rizzo, E.; Bottero, J.-Y.; Bégassat, P. Groundwater redox conditions and conductivity in a contaminant plume from geoelectrical investigations. Hydrol. Earth Syst. Sci. 2004, 8, 8-22. [CrossRef]

18. Cui, Y.A.; Liu, L.; Zhu, X. Unscented Kalman filter assimilation of time-lapse self-potential data for monitoring solute transport. J. Geophys. Eng. 2017, 14, 920-929. [CrossRef]

19. Rittgers, J.B.; Revil, A.; Karaoulis, M.; Mooney, M.A.; Slater, L.D.; Atekwana, E.A. Self-potential signals generated by the corrosion of buried metallic objects with application to contaminant plumes. Geophysics 2013, 78, EN65-EN82. [CrossRef]

20. Naudet, V.; Gourry, J.C.; Girard, F.; Mathieu, F.; Saada, A. 3D electrical resistivity tomography to locate DNAPL contamination around a housing estate. Near Surf. Geophys. 2014, 12, 351-360. [CrossRef]

21. Schüring, J.; Schlieker, M.; Hencke, J. Redox Fronts in Aquifer Systems and Parameters Controlling their Dimensions. In Redox: Fundamentals, Processes and Applications; Schüring, J., Schulz, H.D., Fischer, W.R., Böttcher, J., Duijnisveld, W.H.M., Eds.; Springer: Berlin/Heidelberg, Germany, 2000; pp. 135-151. ISBN 978-3-662-04080-5.

22. Water Basin Agency Oum Rabiaa. Etude D'actualisation du Plan Directeur D'aménagement Intègre des Ressources en eau (PDAIRE) de la Zone D'action de L'agence du Bassin Hydraulique de L'OUM Er Rbia: Données Génerales sur la Plaine du Tadla; Water Basin Agency: Rabat, Morocco, 2008.

23. Massoni, C.; Missante, G.; Beaudet, G.; Combes, M.; Etienne, H.P.; Ionesco, T. La plaine du Tadla. Cah. Rech. Agron. 1967, 24, 163-194.

24. Merzouki, H.; Hanine, H.; Lekhlif, B.; Latrache, L.; Mandi, L.; Sinan, M. Physicochemical Characterization of Leachate Discharge Fkih Ben Salah from Morocco. J. Mater. Environ. Sci. 2015, 6, 1354-1363.

25. WHO. Millennium Development Goals (MDGs); World Health Organization: Geneva, Switzerland, 2018. 
26. Petiau, G. Second Generation of Lead-lead Chloride Electrodes for Geophysical Applications. Pure Appl. Geophys. 2000, 157, 357-382. [CrossRef]

27. Van Loon, G.W.; Duffy, S.J. Environmental Chemistry: A Global Perspective, 4th ed.; Oxford University Press: Oxford, UK, 2017.

28. Naudet, V.; Revil, A. A sandbox experiment to investigate bacteria-mediated redox processes on self-potential signals. Geophys. Res. Lett. 2005, 32. [CrossRef]

29. Delong, E. L'électricité bactérienne,plus qu'une curiosité. Recherche 2002, 358, 17.

30. Tender, L.M.; Reimers, C.E.; Stecher, H.A.; Holmes, D.E.; Bond, D.R.; Lowy, D.A.; Pilobello, K.; Fertig, S.J.; Lovley, D.R. Harnessing microbially generated power on the seafloor. Nat. Biotechnol. 2002, 20, 821-825. [CrossRef] [PubMed] 